\title{
Effect of Harvesting Damages on Cyanide Levels in Different Tuber Zones of Two Commonly Cultivated Cassava Varieties in Mapalana, Sri Lanka
}

P.A.B.N. Perumpuli*, S.M.S.J.M. Singharathne

\section{${ }^{1}$ Department of Food Science and Technology, Faculty of Agriculture, University of Ruhuna, Mapalana, Kamburupitiya, Sri Lanka. \\ Correspondence: \\ *buddhikap@fst.ruh.ac.lk \\ (iD https://orcid.org/0000-0002-8397-493X}

DOI: http://doi.org/10.4038/sljae.v3i1.64

\begin{abstract}
Cassava is one of the staple foods consumed in developing countries. However, it contains cyanogenic glucoside which turns into toxic compound hydrogen cyanide (HCN) when damaged to the cells of cassava tubers. HCN levels of damaged and undamaged locally grown cassava varieties (MU 51 and Kirikawadi) were determined during harvesting using the titrimetric method. The results showed that the HCN level of undamaged MU 51 (14.69 $\left.\pm 1.69 \mathrm{mgkg}^{-1}\right)$ was significantly higher $(p<0.05)$ than that of the undamaged Kirikawadi $(12.46 \pm 0.58$ $\mathrm{mgkg}^{-1}$ ) variety. The HCN level of damaged MU 51 (18.18 $\left.\pm 2.83 \mathrm{mgkg}^{-1}\right)$ was also significantly higher $(p<0.05)$ than the damaged Kirikawadi variety $(15.07 \pm 3.26$ mgkg $^{-1}$ ). Moreover, the HCN levels of both varieties were lower than the recommended safe limit of $50 \mathrm{mg}$ HCN by Codex Alimentarius Commission. Further, it was found that the HCN levels of damaged tubers were significantly $(p<0.05)$ higher than that of undamaged tubers of both varieties. The tuber cortex contained higher HCN levels followed by the parenchyma and pith. In addition, the proximal part (close to stem) of the tuber contained higher HCN levels compared to central and distal parts. However, radial HCN levels from cortex to pith showed a sharp negative gradient than the longitudinal HCN level from proximal to distal part of both cassava varieties. Further, HCN levels of damaged sites were found to be high and showed a reducing gradient from the damaged end of both varieties. Therefore, damaged cassava tubers can be consumed after removing peripheral parts at least up to $5 \mathrm{~cm}$ from the damaged end.
\end{abstract}

Keywords: Damaged tubers, HCN level, Kirikawadi, MU 51 


\section{Introduction}

Manihot esculenta Crantz i.e., Cassava or Manioc, is considered a major staple food and a livestock feed in many developing countries (Li et al. 2013). It is considered the fourth largest carbohydrate source in developing countries followed by rice, wheat and maize (FAO 1986). Starchy tuberous roots are the main source of food, and boiled cassava roots are commonly consumed food source in tropics. In addition, the young leaves that are rich in protein are also consumed in Africa (Dahniya 1994; Mahungu et al. 1998) and Sri Lanka. According to Plucknett, et al. (2001), low cost of production in cassava has guaranteed it as a potential food source of ensuring both the livelihood and food security. Moreover, recently it has become a major horticultural export commodity which helps earning foreign exchange in Sri Lanka (Mudalige 2010).

Other than its nutritional and commercial benefits, cassava is known for high level of cyanide, which is a toxic compound that limits its utility as a food. There are two types of cyanogenic glycoside compounds namely linamarin and lotaustralin present in cassava (Cutler and Conn 1981). Linamarin is the most important and abundant cyanogenic compound which is mainly concentrated in the leaves and the root cortex (Cardoso et al. 2005). Maceration of plant parts release intracellular $\beta$-glucosidase enzyme, and it comes into contact with the cyanogenic glucosides. Eventually, this releases glucose and acetone cyanohydrin, and under neutral or alkaline conditions, it rapidly decomposes into hydrogen cyanide (HCN), the major toxic compound in cassava (Greenwood and Earnshaw 1997; Orjiekwe et al. 2013).

The level of cyanide toxicity of cassava strains depends on geographical location, altitude, harvesting period, crop variety and seasonal conditions (Ndam et al. 2019). Moreover, the number of cyanogenic compounds and the level of toxicity of cassava grown under drought periods are higher than that of cassava grown under rainy conditions. This is mainly due to the water stress occurred during rainy period (Tata-Hangy et al. 2005; Ojo et al. 2013). Furthermore, Srihawong et al. (2015) stated that the cyanogenic glycoside concentration of drought-stressed cassava was significantly higher than that of irrigated plants.

According to them, drought condition may cause a reduction in plant growth, that will result in less protein synthesis. This will lead to higher cyanogenic glycoside content in plants grown under drought conditions 
as they are not being degraded to use as a source of amino acid. According to the Food and Agriculture Organization (FAO) and World Health Organization (WHO) (1995) recommendations, the maximum acute dietary exposures to total $\mathrm{HCN}$ is $10 \mathrm{mg}$ per $1 \mathrm{~kg}$ of body weight. Nevertheless, according to Codex (2005), the maximum level of HCN in sweet cassava in fresh weight basis was recorded as $50 \mathrm{mg}$. However, children are especially vulnerable to above dosage as they have low bodyweight.

Due to the presence of toxic cyanogenic glycosides (linamarin and methyllinamarin), consumption of unprocessed cassava associated with several health issues such as thyroid gland problems and stunting in children including some neurological disorders. In addition to that, ingestion of cassava with high level cyanogen causes headache, vomiting, diarrhea, and dizziness (Cereda and Mattos 1996; Mburu et al. 2013; Dufour 2007). As the situation is such, proper processing: peeling, boiling, soaking, drying etc. is required before eating cassava.

In Sri Lanka, two improved cassava varieties named MU 51 and Kirikawadi are commonly consumed. However, damaging cassava tubers during harvesting is a common problem in cassava cultivation, and consumers are hesitant to consume such damaged cassava tubers due to the risks associated with HCN. Therefore, we determined the cyanide levels of undamaged and damaged cassava tubers of MU 51 and Kirikawadi. Secondly, we also determined the distribution of $\mathrm{HCN}$ in proximal, central and distal parts of cassava tubers. This study set the benchmarks for utilizing damaged cassava tubers in processing of different value-added products such as cassava flour, cassava chips, glucose syrup.

\section{Materials and Methods}

\section{Study location and sample selection}

Fresh cassava tubers of MU 51 and Kirikawadi were purchased soon after harvesting from the farm of the Faculty of Agriculture, University of Ruhuna, Mapalana, Sri Lanka. The farm is located in low country wet zone where an annual precipitation about $2385 \mathrm{~mm}$ is received. The low humic gley and red yellow podzolic soils with heavily mottled subsoils are major soil types that can be seen in the Mapalana (Weerasinghe and Katulanda 1988). The selected tuber samples were categorized as damaged and undamaged roots and samples were analyzed within 46 hours after harvesting. All the experiments were carried out at the Research Laboratory, Faculty of 
Agriculture, University of Ruhuna, Sri Lanka.

\section{Sample preparation}

Three separate cassava tubers were randomly selected from each variety from one harvest, following completely randomized design. Cassava samples were cleaned and thoroughly washed with water to remove soil particles. Cleaned tuberous roots from each variety were separated, and peeled. Then, both damaged and undamaged cassava tuberous roots were cut into three separate parts (proximal, central, distal) and $10 \mathrm{~g}$ of sub-samples from cortex, parenchyma and pith were taken for the analysis of the HCN content. All analysis was completed within four to six hours from harvesting.

\section{Determination of cyanide level by titrimetric method}

Hydrogen cyanide was determined by using silver nitrate volumetric analysis according to the Association of Official Analytical Chemists (AOAC) official method 915.03 (AOAC, 2000). Tuber parts collected from the cortex, parenchyma and pith of the proximal, central and distal parts of the cassava roots from MU 51 and Kirikawadi were ground separately into smaller particles using the mortar and pestle. After mixing with $200 \mathrm{~mL}$ of distilled water, the grounded homogenized samples were soaked for four hours. Thereafter, the soaked samples were distillated until 150 $\mathrm{mL}$ of the distillate was collected, and 8.0 $\mathrm{mL}$ of $6 \mathrm{~N} \mathrm{NH} \mathrm{NH}_{4} \mathrm{OH}$ and $2 \mathrm{~mL}$ of $5 \%(\mathrm{w} / \mathrm{v}) \mathrm{KI}$ were added. Finally, the obtained mixture was titrated with $0.02 \mathrm{~N} \mathrm{AgNO}_{3}$ until the mixture becomes faint but permanently turbid. One milliliter of $\mathrm{AgNO}_{3}$ used in titration is considered to be equivalent to $1.08 \mathrm{mg}$ of HCN (AOAC, 2000), and this relationship was considered in calculating the HCN level in each tested sample.

\section{Statistical Analysis}

Results represent mean values of three samples of each cassava variety taken in triplicate determination, and the HCN values were expressed mean plus or minus the standard deviation (mean \pm SD). Analysis of data was done using Minitab version 17 statistical software. T-test was used to determine statistical difference $(p<0.05)$ between cyanide levels of damaged and undamaged MU 51 and Kirikawadi tubers. One-way ANOVA was used to determine the statistical difference between cyanide levels of pith, cortex and parenchyma; and proximal, central and distal parts of MU 51 and Kirikawadi. In addition, ANOVA test was also used to determine the statistical significance among the HCN levels of cassava tubers measured away from the damaged site of MU 51 and Kirikawadi. 


\section{Results and Discussion}

Initially, the HCN levels of two commonly grown cassava varieties in Sri Lanka, MU 51 and Kirikawadi were examined. Our results revealed that the HCN level of the variety MU $51\left(14.69 \pm 1.69 \mathrm{mgkg}^{-1}\right)$ was found to be significantly higher $(p<0.05)$ than that of the variety Kirikawadi $(12.46$ $\pm 0.58 \mathrm{mgkg}^{-1}$ ). According to Bourdoux et al. (1982), cassava varieties are classified into three major classes as sweet, average toxic and bitter depending on their cyanogenic glycoside content. Accordingly, the linamarin content calculated for the edible part varies in the order of $<50,50-100$, and $>100$ mgkg $^{-1}$ in sweet, average toxic and bitter varieties, respectively. As a result, the bitterness in cassava has become a guide for determining the relative toxicity. Accordingly, both MU 51 and Kirikawadi can be categorized as sweet cassava varieties. Furthermore, Rajapaksha et al. (2017) report that the HCN content of MU 51 on dry basis as 33.92 mgkg-1 $^{-1}$ However, the value obtained in the current study, which is calculated on fresh weight basis was found to be less than the above value. In contrast, higher values in dry basis can be resulted due to the high concentration of the soluble compounds. Moreover, the HCN level of cassava tubers can be varied due to its geographical location, altitude where the crop is grown, harvesting period, and seasonal conditions (Ndam et al. 2019). Furthermore, the cyanide content among cassava roots from the same cultivar from different agro-ecological zones was found to be significantly varied (Mburu et al. 2013). Thus, the HCN level of cassava tubers of the same variety grown in two different geographical locations can be different from each other. Furthermore, according to the FAO and WHO (1995) recommendations, the edible limit of $\mathrm{HCN}$ for human consumption is $10 \mathrm{mgkg}^{-1}$, and however, the values of both tested varieties in their fresh weight basis are higher than the safe limit. Moreover, the HCN level of different cassava varieties can be varied in a range of $15-400 \mathrm{mgkg}^{-1}$ fresh weight.

The variation of HCN level from the cortex to the pith of cassava tubers of each variety was examined. The HCN levels of both varieties were reduced from the center of the cassava tuber, where the highest level was observed in the cortex, and the lowest in the pith (Table 1). The HCN levels were significantly different $(p<0.05)$ among the cortex, parenchyma and the pith, which was prominent in the variety MU 51. Previous studies report that the cyanide level in the cortex of cassava tubers varies in a range of 900-2000 mg/kg (Burns et al. 2011; Cardoso et al. 2005), and that of the 
parenchyma as 1-1500 mg (Mlingi and Bainbridge 1994; Nambisan 1994; Nambisan and Sundaresan 1994). However, our results showed that the HCN levels of the cortex of MU 51 and Kirikawadi were much lower than the previously reported values, and in contrast the HCN levels of the parenchyma of both varieties were in accordance with Mlingi and Bainbridge (1994). In a comparison of the HCN level from cortex to the pith of two cassava varieties called Mariwa and Nyakatanegi, found to be the highest in the cortex (Gervason et al. 2017). A similar study by Ndam et al. (2019) on the influence of cassava cultivars on cyanide content mentions that the cassava cortex contains higher level of HCN compared to the parenchyma in the tubers. This variation of HCN levels in different parts of cassava tubers can be mainly due to the variation in the translocation of cyanogenic glycosides and also their mobilizing enzymes (Siritunga and Sayre 2003). The cyanogens which are responsible for the bitter taste in cassava are mainly produced by enzymatic hydrolysis of linamarin, lostaustralin, and acetone cyanohydrin. Out of them, linamarin is the most important cyanogenic compound, and is synthesized in the leaves through $\mathrm{N}$-hydroxylation of valine and isoleusine. This will be later transported to roots and will stored in vacuoles of cassava cells which are more concentrated in leaves and root cortex compared to paranchyma (Cardso et al., 2005). As a whole, due to its higher level of HCN content, it is advisable to remove the cassava peel properly before further processing (Ubwa et al. 2015). Further, HCN levels of proximal, distal and central parts from the stem of the undamaged cassava tubers of both varieties were also examined (Table 2). Even though it is not significantly different, the highest mean values were shown in the proximal (close to stem) part of both varieties followed by the central and the distal parts (Table 2). According to Bokanga (1999) and Hidayat et al. (2002), cyanide level is higher in newly generating tissues than in old tissues. Further, they reveal the HCN levels in cassava tubers decrease from the proximal to the distal end. Moreover, the difference of HCN level along the radial axis is higher than the longitudinal axis of undamaged cassava tubers. Likewise, the same pattern was observed in this study. In variety MU 51, the radial gradient for HCN was found as -1.695 and the longitudinal gradient was -1.22 , and in the variety Kirikawadi, the radial gradient was calculated as -0.47 and the longitudinal gradient was -0.14 (Table 3 and 4). 
Subsequently, the HCN levels of both damaged and undamaged cassava tubers of both varieties were also examined (Table 3). A significant increase in the cyanide level of the cassava tubers was observed in damaged tubers of both varieties (Table 3 ). Damages caused to the cassava tubers increase the releasing of $\beta$-glucosidase enzymes are responsible for the decomposition of cyanogenic glucosides. Moreover, mechanical damage of cells also enhances the HCN production through the release of linamarase from the cassava root cells (Ojo et al. 2013).

Table 1. Comparison of HCN contents in cortex, parenchyma, and pith of cassava tubers of MU51 and Kirikawadi varieties grown in Mapalana, Sri Lanka

\begin{tabular}{|c|c|c|c|c|}
\hline & Variety & 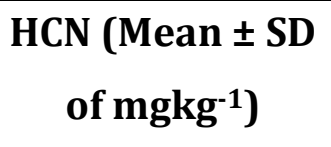 & $p$ value & Radial gradient \\
\hline & Cortex & $16.36 \pm 0.31^{\mathrm{a}}$ & & \\
\hline \multirow[t]{3}{*}{ MU 51} & Parenchyma & $14.74 \pm 1.16^{\mathrm{a}}$ & 0.015 & -1.695 \\
\hline & Pith & $12.97 \pm 1.17^{b}$ & & \\
\hline & Cortex & $13.09 \pm 0.62^{a}$ & & \\
\hline \multirow[t]{2}{*}{ Kirikawadi } & Parenchyma & $12.13 \pm 0.09 b$ & 0.041 & -0.47 \\
\hline & Pith & $12.15 \pm 0.29 b$ & & \\
\hline
\end{tabular}

Table 2. Comparison of HCN content along the longitudinal axis of undamaged cassava tubers of MU 51 and Kirikawadi varieties grown in Mapalana, Sri Lanka

HCN (Mean \pm SD of mgkg-1) $^{-1}$

\begin{tabular}{lllll}
\hline & Proximal & Central & Distal & $\begin{array}{l}\text { Longitudinal } \\
\text { gradient }\end{array}$ \\
\hline MU 51 & $15.82 \pm 0.61^{\mathrm{a}}$ & $15.24 \pm 1.12^{\mathrm{a}}$ & $13.38 \pm 1.46^{\mathrm{a}}$ & -1.22 \\
\hline Kirikawadi & $12.63 \pm 0.95^{\mathrm{a}}$ & $12.56 \pm 0.53^{\mathrm{a}}$ & $12.35 \pm 0.21^{\mathrm{a}}$ & -0.14
\end{tabular}

Means with similar superscript in each row does not significantly different from each other. All the values are reported in the fresh weight basis.

This enhance the HCN production in damaged parts of the cassava roots. Subsequently, glucose and acetone cyanohydrin are released and the produced acetone cyanohydrin is converted into HCN under neutral and alkali conditions. The tubers damaged during harvesting and 
other handling steps accelerate the above condition.

Moreover, the HCN levels of the damaged tubers were found to be significantly higher $(p<0.05)$ than FAO and WHO recommendations of $\mathrm{HCN}, 10 \mathrm{mgkg}^{-1}$. This reveals that it is risky to consume damaged cassava tubers without

processing, especially for children with low bodyweight. However, according to Codex (2005), our tested samples are within the safe limit. Moreover, in the current study analysis of HCN level in the damaged tuber was examined soon after harvesting. Since production of $\mathrm{HCN}$ in damaged tubers is a series of enzymatically controlled chemical reactions, the production of $\mathrm{HCN}$ can be a time dependent reaction. Thus, the HCN levels of damaged tubers should be examined after several intervals from harvesting. We suggest that the utilization of damaged cassava tubers in processing and human consumption need to be limited. Thus, the HCN level of the parenchyma from two different distances of the damaged cassava tubers was examined.

Table 3. The HCN levels of damaged and undamaged cassava tubers of MU 51 and Kirikawadi varieties grown in Mapalana, Sri Lanka

\begin{tabular}{lllll}
\hline Variety & \multicolumn{1}{c}{$\begin{array}{c}\text { HCN (Mean } \pm \text { SD of } \\
\text { mgkg }^{-1} \text { ) }\end{array}$} & T value & $p$ value \\
\hline \multirow{2}{*}{ MU 51 } & Undamaged & $14.69 \pm 1.69^{\mathrm{b}}$ & 1.29 & 0.023 \\
& Damaged & $18.18 \pm 2.83^{\mathrm{a}}$ & & \\
\multirow{2}{*}{ Kirikawadi } & Undamaged & $12.46 \pm 0.58^{\mathrm{b}}$ & -2.32 & 0.049 \\
& Damaged & $15.07 \pm 3.26^{\mathrm{a}}$ & & \\
\hline
\end{tabular}

Means with similar superscript in each variety does not significantly different $(p<0.05)$ from each other. All the values are reported in the fresh weight basis.

Table 4. The HCN levels of cassava tubers measured away from the damaged site of MU 51 and Kirikawadi varieties grown in Mapalana, Sri Lanka

HCN Level (Mean \pm SD of mgkg $^{-1}$ )

\begin{tabular}{llll}
\cline { 2 - 4 } Variety & At damaged site & $\begin{array}{l}\text { At } \mathbf{5} \mathbf{~ c m} \text { away from } \\
\text { damaged site }\end{array}$ & $\begin{array}{l}\text { At } \mathbf{1 0} \text { cm away from } \\
\text { damaged site }\end{array}$ \\
\hline MU 51 & $18.23 \pm 2.08^{\mathrm{a}}$ & $13.55 \pm 1.31^{\mathrm{b}}$ & $13.43 \pm 1.19 \mathrm{~b}$ \\
Kirikawadi & $16.93 \pm 1.02^{\mathrm{a}}$ & $15.27 \pm 0.91^{\mathrm{a}}$ & $15.51 \pm 2.59^{\mathrm{a}}$ \\
\hline
\end{tabular}

Means with similar superscript in each row does not significantly $(p<0.05)$ different from each other. All the values are reported in the fresh weight basis. 
A significant reduction $(p<0.05)$ in cyanide level was observed in both MU 51 and Kirikawadi varieties, and a considerable amount of HCN was observed even at $10 \mathrm{~cm}$ depth from the damaged end (Table 4). Moreover, the cyanide level in the parenchyma of the tubers at $10 \mathrm{~cm}$ depth from the damaged site was found to be more or less similar to level found in the 5 cm depth. Furthermore, no significant difference $(p<0.05)$ was observed between the HCN level of neither in $5 \mathrm{~cm}$ nor in 10 $\mathrm{cm}$ depth from the damaged end. All these values were higher than the FAO and WHO recommendations. However, our results were within the Codex (2005) safe limit. Accordingly, the damaged cassava tubers can be used in further processing after removing the damaged part at least $15 \mathrm{~cm}$ from the damaged end. Moreover, the level of HCN in cassava tubers could be reduced by further processing.

\section{Conclusion}

We found that the HCN content in the variety MU 51 is a higher than the variety, Kirikawadi. The HCN levels of the cassava tubers are high in the cortex, which decrease towards the pith. The HCN level of cassava tubers at the damaged end is much higher, which reduces gradually towards the undamaged side.
All the obtained HCN levels throughout the study were found to be within the safe limit of sweet cassava. However, it is advisable to remove at least a $15 \mathrm{~cm}$ portion from the damaged end for further processing. Moreover, the HCN level in both damaged and undamaged cassava varieties could be reduced up to FAO and WHO recommended safety limits for the consumption through further processing techniques for which further studies need to be carried out.

Conflicts of interest: The authors have no conflicts of interest regarding this publication.

\section{References}

Association of Official Analytical Chemist (AOAC), (2000) Official Method of Analysis (15 th ed.) Washington D.C. 915.03

Bokanga M (1999) Cassava Post-Harvest Operations. International Institute of Tropical Agriculture, pp. 23.

Bourdoux P, Seghers P, Mafuta M, Vandrpas-Rivera M, Delange F and Ermans, A M (1982) Cassava products: HCN content and detoxification process, in: F Delange, $F$ B Iteke, A M Ermans (ed.), Nutritional factors involved in the goitrogenic action of cassava. IDRC-184e. IDRC, Ottawa, Canada, pp. 51-58. 
Burns A E, Bradbury J H, Cavagnaro T R and Gleadow R M (2011) Total cyanide content of cassava food products in Australia. Annual Journal of Food Composition, 25, pp.79-82.

Cardoso A P, Mirione E, Ernesto M, Massaza F, Cliff J, Rezaul-Haque M and Bradbury J H (2005) Processing of cassava roots to remove cyanogens. Journal of Food Composition and Analysis, 18(5), pp.451460.

Cereda M P and Mattos M C Y (1996) Linamarin: the toxic compound of cassava. Journal of Venomous Animals and Toxins. 2(1), pp.06-12.

Cutler A and Conn E (1981) The biosynthesis of cyanogenic glycosides in Linum usitatissumum (Linen flax) in vitro. Achieves in Biochemistry and Biophysics, 212, pp. 468-474.

Dahniya M T (1994) An overview of cassava in Africa. African Crop Science Journal 2, pp. 337-343.

Dufour D L (2007) Bitter Cassava: Toxicity and Detoxification Proceedings of First International Meeting on Cassava Breeding, Biotechnology and Ecology. University of Brazil 171-184.
FAO (1986) The role of roots, tubers and plantains in food security in sub-Saharan Africa. Committee on World Food Security, Eleventh Session, Rome pp. 21

Codex (2005) Codex standard for sweet cassava. Codex Stan 238-2003, Rome, 14 May 2021, Codex Alimentarius http://www.codexalimentarius.org/standa rds/list-of-standards/

Food and Agriculture Organization and World Health Organization (1995) Codex standard for edible cassava flour. Codex Standard, pp.176-1989.

Gervason M, Ben 0, Bibianne W, Edith W and Jared $O$ (2017) Evaluation of Cyanide Levels in Two Cassava Varieties (Mariwa and Nyakatanegi) Grown in Bar-agulu, Siaya County, Kenya. Journal of Food and Nutrition Research, 5(11), pp.817-823.

Greenwood N and Earnshaw A (1997) Chemistry of the Elements (2nd ed.) Oxford Butterworth-Heinemann.

Hidayat A, Zuraida N and Hanarida I (2002) The cyanogenic potential of roots and leaves of ninety-nine cassava cultivars. Indonesian Journal of Agricultural Science, 3(1), pp.25-32. 
Li L, Zhang L and Zhang F (2013) Crop Mixtures and the Mechanisms of Overyielding. Encyclopedia of Biodiversity, pp. 382-395.

Mahungu N M, Kanju E, Kulembeka S M, Tollano S, M, Massawe M H and Masumba, E (eds) (1998). Screening cassava for resistance to cassava brown streak disease. Proceedings of the Southern African Root Crops Research Network (SARRNET). August 17-19, 1998: Food Security and Crop Diversification in SADC Countries: The Role of Cassava and Sweet Potato. Zambia.

Mburu F W, Sweleh S and Njue W (2013) Potential toxic levels of cyanide in cassava (Manihot esculenta Crantz) grown in Kenya. African Journal of Food Science, pp.416-420.

Minitab 17 Statistical Software (2010) Computer Software. State college, PA, Minitab Inc. (www.minitab.com)

Mlingi N L V and Bainbridge Z (1994) Reduction of cyanogen levels during sundrying of cassava in Tanzania. Acta Horticulturae,375, pp. 233-239.

Mudalige U K J (2010) Role of food and agriculture sector in economic development of Sri Lanka: Do we stand right in the process of structural transformation? Journal of Food and Agriculture,1, pp.1-12.

Nambisan B (1994) Evaluation of the effect of various processing methods on cyanogen content reduction in cassava. Acta Horticulturae,375, pp. 193-201.

Nambisan B and Sundaresan S (1994) Distribution of linamarin and its metabolizing enzymes in cassava tissues. Journal of the Science of Food and Agriculture,66, pp. 503-507.

Ndam N, Mounjouenpou P, Kansci G, Kenfack M J, Priscile M, Sophie N, Akhobakoh M M and Nyegue A (2019) Influence of cultivars and processing methods on the cyanide contents of cassava (Manihot esculenta Crantz) and its traditional food products. Scientific African,5, pp.119.

Ojo, R T, Obi N P, Akintayo C O and Adebayo-Gege G I (2013) Evaluation of Cyanogen Contents of Cassava and Cassava Based Food Products in Karu, Nasarawa State, North Central Nigeria. IOSR Journal of Environmental Science, Toxicology and Food Technology,6(1), pp. 47-50.

Orjiekwe C, Solola A, Iyen E and Imade S (2013) Determination of cyanogenic 
glucosides in cassava products sold in Okada, Edo State, Nigeria. African Journal of Food Science ,7(12), pp. 468-472.

Plucknett D, Phillips $\mathrm{T}$ and Kagbo $\mathrm{R}$ (2001) The global cassava development strategy and implementation plan. Rome: Food and Agricultural Organization of the United Nations.

Rajapaksha K D S C N, Somendrika M A D and Wickramasinghe I (2017) Nutritional and toxicological composition analysis of selected cassava processed products. Slovak Journal of Food Science ,11, pp.35-42.

Siritunga D and Sayre R $T$ (2003) Generation of cyanogen-free transgenic cassava. Planta, 217, pp. 367-373.

Srihawong W, Kongsil P, Petchpoung K and Sarobol E (2015) Effect of Genotype, Age and Soil Moisture on Cyanogenic Glycosides Content and Root Yield in Cassava (Manihot esculenta Crantz). Kasetsart Journal (Nat. Sci),49, pp.844-855.
Tata-Hangy K, Hanna R, Toko M and Solo M (2005) Effect of cassava leaf harvest on a cassava green mite predator in the Democratic Republic of Congo. African Crop Science Journal ,12(3), pp. 289-293.

Ubwa S, Otache M, Igbum G, Shambe T (2015) Determination of Cyanide Content in Three Sweet Cassava Cultivars in Three Local Government Areas of Benue State, Nigeria. Food and Nutrition Sciences ,6, pp.1078-1085.

Weerasinghe $\mathrm{K} \mathrm{D} \mathrm{N}$ and Katulanda $\mathrm{W}$ (1988) Evapotranspiration requirement of rice at Mapalana in the wet zone of southern Sri Lanka. Journal of the National Science Foundation of Sri Lanka,16, pp. 115124. 